\title{
Intercropping of Gramineous Pasture Ryegrass (Lolium perenne L.) and Leguminous Forage Alfalfa (Medicago sativa L.) Increases the Resistance of Plants to Heavy Metals
}

\author{
Tuantuan Cui, ${ }^{1}$ Linchuan Fang $\mathbb{D}^{1,2}$ Mengke Wang, ${ }^{1}$ Mao Jiang, ${ }^{1}$ and Guoting Shen ${ }^{1}$ \\ ${ }^{1}$ College of Natural Resources and Environment, Northwest A\&F University, Yangling 712100, China \\ ${ }^{2}$ State Key Laboratory of Soil Erosion and Dryland Farming on the Loess Plateau, Northwest A\&F University, \\ Yangling 712100, China
}

Correspondence should be addressed to Linchuan Fang; flinc629@hotmail.com

Received 5 January 2018; Revised 29 March 2018; Accepted 15 April 2018; Published 5 July 2018

Academic Editor: Xiao-San Luo

Copyright (C) 2018 Tuantuan Cui et al. This is an open access article distributed under the Creative Commons Attribution License, which permits unrestricted use, distribution, and reproduction in any medium, provided the original work is properly cited.

Intercropping can increase the biomass of plants and reduce the accumulation of heavy metals in plants. However, the mechanisms of intercropping increasing plant biomass and resistance to heavy metals are still unclear. Therefore, the pot experiment had been conducted to investigate the effect of intercropping treatment on the growth of gramineous pasture ryegrass (Lolium perenne L.) and leguminous forage alfalfa (Medicago sativa L.) in metal-contaminated soil. Our results showed that intercropping alleviated inhibition of heavy metals to plant growth and increased nitrogen and chlorophyll contents in the shoots and roots. Moreover, the $\mathrm{Pb}$ concentrations in the shoots and roots of ryegrass and alfalfa in the intercropping were significantly lower than those in the monoculture. And, the contents of saccharase and alkaline phosphatase were significantly increased in the intercropping treatment. Additionally, the intercropping treatment could reduce the oxidative damage and increase enzymatic antioxidant activities to improve the resistance of plants in contaminated soil. The intercropping treatment can increase the resistance of plants to heavy metals through reduction of plant oxidative damage and increase of antioxidant activity. It could provide us with a strategy that intercropping of ryegrass and alfalfa can increase biomass and reduce the absorption of $\mathrm{Pb}$ on forage plants.

\section{Introduction}

Heavy metals pollution has become a serious environmental problem, posing significant risk to human health as well as to ecosystems [1, 2]. Therefore, remediating heavy metalcontaminated soil has received a worldwide concern. Phytoremediation has several advantages such as ease of operation in the field, relatively low cost, and soil improvement without secondary pollution; therefore, it has become one of the major methods for the remediation of heavy metal-polluted soils [3]. Techniques of phytoremediation include phytoextraction, phytofiltration, phytostabilization, phytovolatilization, and phytodegradation [4]. Phytostabilization is the use of certain plants and strategies for stabilization of contaminants in contaminated soils [5].

Intercropping is one of the traditional agricultural managements, which has shown the improvement of land use efficiency [6]. Intercropping had been used to remediate heavy metal-polluted soils and was found to have many advantages [7]. It has been reported that intercropping can not only increase plant biomass but also change the accumulation of heavy metals in plants [8]. Intercropping can also produce agricultural products while cleaning the heavy metal-contaminated soil [9]. Intercropping has been proposed as an alternative to phytostabilization for heavy metal-contaminated soil [10]. However, the mechanisms of intercropping influencing heavy metal accumulation and biomass in plants remain unclear.

Over 100 intercropping combinations currently have been applied in China, 70\% of the combined groups are including leguminous crops [11]. It has been found that the intercropping of gramineous and leguminous could enhance plant nutrients availability and uptake which supply substances to promote plant growth $[12,13]$. Leguminous and gramineous intercropping systems are widely used, due to 
the ability of nitrogen fixation by leguminous crops. Under leguminous and gramineous intercropping systems, the part of $\mathrm{N}$ fixed by leguminous plant can be transferred through various channels and then be used by the gramineous crops, so as to improve $\mathrm{N}$ utilization efficiency $[14,15]$. For example, the intercropping system of gramineous wheat and leguminous soybean can substantially increase wheat yield and promote nutrient utilization [6].

Ryegrass (Lolium perenne L.) is widely reported as a kind of pasture which is suitable for planting in heavy metalcontaminated soil [16-19]. Previous studies have demonstrated that ryegrass could potentially rehabilitate $\mathrm{Cd}$ - and $\mathrm{Pb}$-contaminated soils $[20,21]$. Alfalfa (Medicago sativa L.) is the important perennial forage and has a wide distribution in the world [22]. Some studies showed that alfalfa has a potential capability to restore heavy metal-contaminated soil [23]. Ryegrass and alfalfa are two important forages in northern China $[22,24]$. Planting these two forages in the heavy metalcontaminated soil would be harmful to the livestock industry. Previous studies showed that intercropping can reduce heavy metals uptake by plants [8]. However, it is still unclear about the uptake characteristics of heavy metals by plant under the intercropping patterns of ryegrass and alfalfa. Furthermore, the mechanisms of intercropping influencing the resistance of plants to heavy metals are also investigated in this study.

We hypothesized that the intercropping of ryegrass and alfalfa could influence the plant growth and the heavy metals resistance. The absorption characteristics of plants were indicated by means of determination of heavy metals content and biomass. The nutritional status of plants was measured by chlorophyll and $\mathrm{N}$ contents. The oxidative damage and enzymatic antioxidants activities were utilized to evaluate the resistance of plant to heavy metals. The objectives of this study were to investigate (1) the effects of intercropping of ryegrass and alfalfa on the uptake characteristics of heavy metals in plants, and (2) the mechanisms of intercropping influencing the resistance of plants to heavy metals. The investigation may provide a better understanding of the mechanism of detoxification of heavy metals by intercropping.

\section{Materials and Methods}

2.1. Sample Preparation. The topsoil $(0-20 \mathrm{~cm})$ was collected from the $\mathrm{Pb}-\mathrm{Zn}$ mine located in Feng County, Shaanxi Province, China $\left(106^{\circ} 36^{\prime} 15^{\prime \prime} \mathrm{E}, 33^{\circ} 52^{\prime} 35^{\prime \prime} \mathrm{N}\right)$. The soil samples were stored in clean Ziploc plastic bags and transferred to the laboratory immediately. The basic physicochemical properties of the soils were determined and are presented in Table 1. Ryegrass and alfalfa seeds were sown in the pots after sterilization with $30 \%$ sodium hypochlorite solution for $2 \mathrm{~min}$, washed three times with tap water, and rinsed with deionized water (DIW).

2.2. Pot Experiment. After the soil was air-dried, it was passed through a $2 \mathrm{~mm}$ sieve. The air-dried soils $(8 \mathrm{~kg}$ per pot) were placed in plastic pots (height: $25 \mathrm{~cm}$; diameter: $25 \mathrm{~cm}$ ). The moisture was maintained at $\sim 60 \%$ of the maximum water-holding capacity to balance one week. And
TABle 1: Soil physical-chemical properties and heavy metals concentration.

\begin{tabular}{ll}
\hline Physical-chemical properties & \\
\hline $\mathrm{pH}(\mathrm{soil}:$ water, $1: 2.5)$ & 8.08 \\
$\mathrm{SOM}\left(\mathrm{g} \cdot \mathrm{kg}^{-1}\right)$ & 25.8 \\
$\mathrm{TN}\left(\mathrm{g} \cdot \mathrm{kg}^{-1}\right)$ & 1.59 \\
$\mathrm{TP}\left(\mathrm{g} \cdot \mathrm{kg}^{-1}\right)$ & 0.31 \\
The total concentration of heavy metals $\left(\mathrm{mg} \cdot \mathrm{kg}^{-1}\right)$ & \\
$\mathrm{Pb}$ & 652 \\
$\mathrm{Cd}$ & 4.95 \\
$\mathrm{Zn}$ & 160 \\
$\mathrm{Cu}$ & 30.1 \\
\hline
\end{tabular}

Note. SOM: soil organic matter; TN: total N; TP: total P.

then the moisture was maintained at $\sim 80 \%$ of the maximum water-holding capacity. No fertilizers were added throughout the experiment. In the control treatment, there was no plant in the pot. In the monoculture treatment, alfalfa and ryegrass were grown separately. In the intercropping treatment, the equidistance between alfalfa and ryegrass was separated. The experiment design is shown in Figure 1, which four different treatments were carried out as follows: (1) control: unplanted soil; (2) MA: monoculture of alfalfa; (3) MR: monoculture of ryegrass; and (4) IAR: intercropping of alfalfa and ryegrass.

Before the seed germination, 100 seeds of the same size were guaranteed in each pot. After 10 days, the seedlings were planted to ensure that 60 germination seeds were planted in each basin, and 30 of each plant were in the intercropping treatment. The pot experiment was performed in a greenhouse under natural light at $22 \sim 28^{\circ} \mathrm{C}$.

2.3. Sampling and Analysis. Soil moisture was determined gravimetrically in fresh soils at $105^{\circ} \mathrm{C}$ to constant weight. Soil $\mathrm{pH}$ of air-dried samples (sieved to $1 \mathrm{~mm}$ ) was determined using the glass electrode (Startorius PB10) with a soil to water (non- $\mathrm{CO}_{2}$ deionized water) ratio of $1: 2.5$. Soil organic matter (SOM) was analyzed using the standard procedure of dichromate [25]. Total nitrogen (TN) was measured by titration. Inorganic $\mathrm{N}$ of $\mathrm{NH}_{4}{ }^{+}$and $\mathrm{NO}_{3}{ }^{-}$was extracted by $2 \mathrm{M} \mathrm{KCl}$, and the extractant was subsequently analyzed using a Seal autoanalyzer. Available phosphorus (AP) was measured using the $0.5 \mathrm{~mol} / \mathrm{L} \mathrm{NaHCO}_{3}$ extraction-ammonium molybdateantimony potassium tartrate and ascorbic acid spectrophotometric method. Soil heavy metals contents were determined by using three acid digestion $\left(\mathrm{HNO}_{3}, \mathrm{HCl}\right.$, and $\left.\mathrm{HClO}_{4}\right)$, and the digested samples were analyzed by ICP-AES technique (inductively coupled plasmaoptical emission spectrometer, PerkinElmer-Optima 7300 DV, USA).

The plants were harvested after 75 days, and the fresh shoots and roots were harvested separately. The fresh shoots were used to measure chlorophyll content using the acetone method immediately. The fresh shoots and roots from each treatment were immediately stored at $-80^{\circ} \mathrm{C}$ for measuring the oxidative damage system and enzyme activity later. The content of malondialdehyde (MDA) was used to evaluate the lipid peroxidation [26]. Briefly, grounded shoot and root samples were extracted by $10 \%$ trichloroacetic acid $(2 \mathrm{~mL})$. 


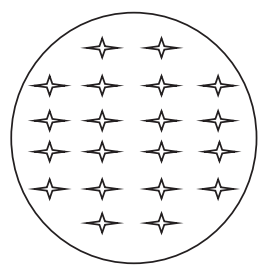

(a)

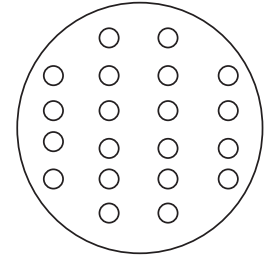

(b)

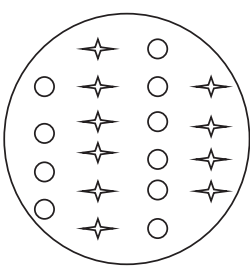

(c)
FIgURE 1: Pot experiment design drawing. (a) Monoculture of ryegrass; (b) Monoculture of alfalfa; (c) Intercropping of alfalfa and ryegrass. \& represents ryegrass; $O$ represents alfalfa.

After centrifugation at $8000 \mathrm{~g}$ for $10 \mathrm{~min}$, the MDA in the supernatant was measured using an MDA reagent kit (Suzhou Comin Biotechnology Co., Ltd. Suzhou, China) based on the absorbance at 532 and $600 \mathrm{~nm}$. The activity of total peroxidase (POD, EC 1.11.1.7), catalase (CAT, EC 1.11.1.6), and ascorbate peroxidase (APX, EC 1.11.1.11) in the shoot and root were correspondingly assessed using the enzyme-specific commercial reagent kit (Suzhou Comin Biotechnology Co., Ltd. Suzhou, China). These activity indicators were determined by the absorbance of the supernatant after reactions at different wavelengths (i.e., 470, 240, and $290 \mathrm{~nm}$ for POD, CAT and APX, resp.) (Epoch, US), following the manufacturer's instructions. The enzyme activities of POD, CAT, and APX were calculated from the initial rate of the reaction using the extinction coefficient of tetraguaiacol, $\mathrm{H}_{2} \mathrm{O}_{2}$, and ascorbate, respectively.

The shoots and roots were thoroughly washed with distilled water before heavy metals analysis. Fresh samples were dried at $105^{\circ} \mathrm{C}$ for 30 mins, and then dried to constant weight at $75^{\circ} \mathrm{C}$. The oven-dried plant samples were digested using $\mathrm{HNO}_{3} / \mathrm{HClO}_{4}(4: 1, \mathrm{v} / \mathrm{v})$ to analyze the concentrations of metals. The nitrogen $(\mathrm{N})$ concentration in plant tissues were determined after concentrated $\mathrm{H}_{2} \mathrm{SO}_{4}$ and $\mathrm{H}_{2} \mathrm{O}_{2}$ digestion by the high resolution automatic chemical analyzer.

After plants were harvested, the soil (through a $2 \mathrm{~mm}$ sieve) was immediately stored in the $4^{\circ} \mathrm{C}$ to measure enzyme activity. Catalase (EC 1.11.1.6) used $\mathrm{H}_{2} \mathrm{O}_{2}$ as the substrate and was quantified with a spectrophotometer (UV3200, Shimadu Corporation, Japan) at $240 \mathrm{~nm}$. Saccharase (EC 3.2.1.26) enzyme activity was analyzed according to the method described by Guan [27]. Alkaline phosphatase assays, following the methods of Eivazi and Tabatabai [28, 29], were quantified on the release of p-nitrophenol at $400 \mathrm{~nm}$. Urease was measured following the method of Guan [27], using urea as the substrate and was quantified at $578 \mathrm{~nm}$.

2.4. Data Analysis. All statistical analysis was carried out in SPSS 21.0 (SPSS Inc, Chicago, USA). The differences of parameters among different treatments (heavy metal concentrations, soil properties, enzyme activities, etc.) were analyzed using one-way ANOVA with LSD test at a 0.05 significance level. Pearson correlation analysis was performed to measure the relationships between enzyme activities and heavy metals, soil properties. All bar graphs were drawn using Origin Pro 9.0 (Origin Lab, Hampton, USA).
TABLE 2: The biomass of ryegrass and alfalfa with different treatments.

\begin{tabular}{lcccc}
\hline \multirow{2}{*}{ Treatments } & \multicolumn{2}{c}{ Ryegrass } & \multicolumn{2}{c}{ Alfalfa } \\
& $\begin{array}{c}\text { Shoot } \\
\left(\mathrm{g} \cdot \text { plant }^{-1}\right)\end{array}$ & $\begin{array}{c}\text { Root } \\
\left(\mathrm{g} \cdot \mathrm{plant}^{-1}\right)\end{array}$ & $\begin{array}{c}\text { Shoot } \\
\left(\mathrm{g} \cdot \text { plant }^{-1}\right)\end{array}$ & $\begin{array}{c}\text { Root } \\
\left(\mathrm{g} \cdot \mathrm{plant}^{-1}\right)\end{array}$ \\
\hline \multirow{2}{*}{ Monoculture } & $0.52 \pm$ & $0.14 \pm$ & $0.34 \pm$ & $0.24 \pm$ \\
& $0.09^{\mathrm{a}}$ & $0.01^{\mathrm{b}}$ & $0.05^{\mathrm{b}}$ & $0.02^{\mathrm{b}}$ \\
\hline \multirow{2}{*}{ Intercropping } & $0.57 \pm$ & $0.18 \pm$ & $0.47 \pm$ & $0.37 \pm$ \\
& $0.07^{\mathrm{a}}$ & $0.03^{\mathrm{a}}$ & $0.04^{\mathrm{a}}$ & $0.05^{\mathrm{a}}$ \\
\hline
\end{tabular}

Note. Values are the means \pm standard error $(n=4)$. Means followed by the same letter are not significantly different at $p<0.05$.

\section{Results}

3.1. Plant Biomass, Chlorophyll, and $N$ Content. Table 2 shows the biomass of plants roots and shoots. For ryegrass, no significant differences were found on the biomass of the shoots between those grown in different planting patterns; the biomass of roots grown in the intercropping treatment was significantly higher than those grown in the monoculture treatment. For alfalfa, compared with the monoculture treatment, the intercropping treatment significantly increased the biomass of shoots and roots.

Nitrogen concentrations in the shoots of ryegrass were substantially improved by the intercropping treatment (Figure 2(a)). The intercropping treatment was significantly increased the nitrogen concentrations in both shoots and roots of alfalfa (Figures 2(a) and 2(b)). In the monoculture treatment of ryegrass, the chlorophyll concentration was $1.7 \mathrm{mg} / \mathrm{g}$, whereas in the intercropping treatment, the chlorophyll concentration was significantly increased to $2.5 \mathrm{mg} / \mathrm{g}$ (Figure 3). The chlorophyll concentrations in alfalfa were 3.2 and $2.6 \mathrm{mg} / \mathrm{g}$ in the monoculture and intercropping treatments, respectively. The chlorophyll concentrations in the intercropping treatment of alfalfa were apparently higher than those in the intercropping treatment.

\subsection{Concentrations and Total Uptakes of Metals in Plants.} The concentrations and total uptakes of metals in ryegrass and alfalfa were presented in Table 3 . The $\mathrm{Pb}$ concentration and total uptake in ryegrass shoots were significantly decreased by $60 \%$ and $56 \%$, respectively, in the intercropping treatment, compared to those in the monoculture treatment. And the $\mathrm{Pb}$ concentration and total uptake in roots were significantly decreased by $50 \%$ and $32 \%$, respectively. The total uptake of $\mathrm{Zn}$ both in shoots and roots of alfalfa was significantly decreased in the intercropping treatment. Compared with the monoculture treatment, there were no significant differences with the concentrations of $\mathrm{Cd}$ and $\mathrm{Zn}$ in the shoots and roots of ryegrass in the intercropping treatment. The intercropping treatment resulted in a significant decrease in the concentrations of $\mathrm{Pb}$ in the shoots and roots of alfalfa by $23 \%$ and $60 \%$, respectively. The concentrations of $\mathrm{Cd}$ were significantly decreased in the shoots of alfalfa by $22 \%$ in the intercropping treatment. Intercropping treatment significantly increased the $\mathrm{Zn}$ total uptake of alfalfa tissues, and no remarkable variations were observed in the $\mathrm{Zn}$ content of the alfalfa. 


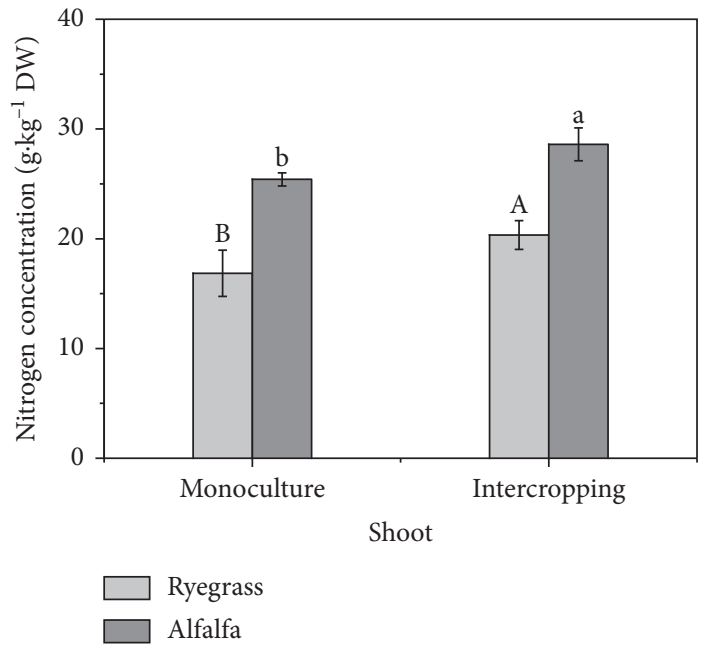

(a)

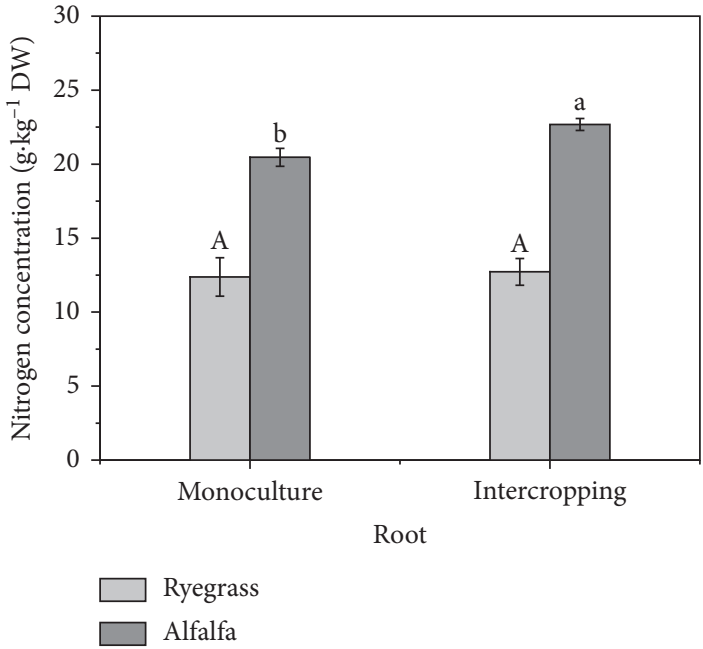

(b)

Figure 2: The nitrogen content in shoots (a) and roots (b) of ryegrass and alfalfa under monoculture and intercropping treatments. Bars are the standard error $(n=3)$. Means followed by the same letter are not significantly different at $(p<0.05)$.

\subsection{Soil Enzymatic Activities and Physicochemical Properties.} The changes of soil enzymes (urease activity, saccharase activity, alkaline phosphatase activity, catalase activity, and polyphenol oxidase activity) are shown in Table 4. The impacts of the planting pattern on soil enzymes were inconsistent and enzyme-specific. Compared with the alfalfa monoculture treatment, the intercropping treatment significantly increased the urease activity but less than the ryegrass monoculture treatment. The saccharase activity in the intercropping treatment was significantly higher than other treatments. The alkaline phosphatase activity showed a similar pattern to the saccharase activity change. After planting the plant, the catalase activity of the soil was increased but showed no remarkable variations among the planning pattern. Compared with the ryegrass monoculture treatment, the polyphenol oxidase activity was significantly increased in the intercropping treatment but showed no differences with other treatments.

The soil physicochemical properties are presented in Table 5 . The soil $\mathrm{pH}$ with planted treatment was significantly higher than those with unplanted treatment. The contents of SOM showed no significant changes among different planning patterns. Compared with the unplanted soil, the $\mathrm{TN}$ and $\mathrm{AK}$ in soil were significantly decreased by the planting pattern of all treatments. There were no significant differences with the concentrations of TN in the soil among different planting patterns. Among all the treatments, the intercropping treatments had the highest soil $\mathrm{NH}_{4}{ }^{+}-\mathrm{N}$ and $\mathrm{NO}_{3}{ }^{-}-\mathrm{N}$. The AP had no change among different treatments.

3.4. Correlation Analysis. The correlations among soil physicochemical properties and soil enzyme activities are presented in Table 6 . The soil urease, saccharase, and catalase were significantly positive correlated with soil $\mathrm{pH}$ and were significantly negative correlated with soil TN. Saccharase was significantly positive correlated with soil $\mathrm{NH}_{4}{ }^{+}-\mathrm{N}$ and

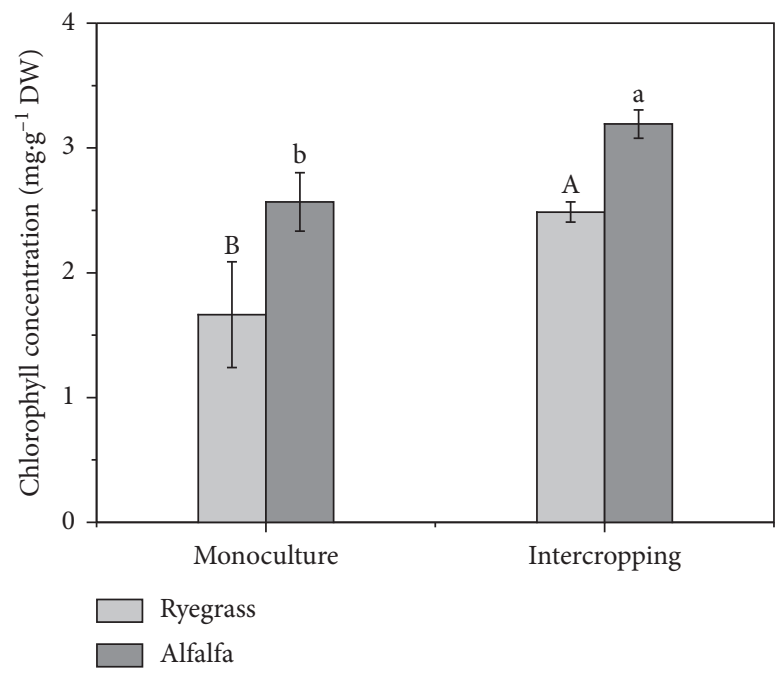

FIgURE 3: The chlorophyll content in shoots of ryegrass and alfalfa under monoculture and intercropping treatments. Bars are the standard error $(n=3)$. Means followed by the same letter are not significantly different at $p<0.05$.

$\mathrm{NO}_{3}{ }^{-}-\mathrm{N}$. Alkaline phosphatase was significantly positive correlated with soil $\mathrm{NO}_{3}{ }^{-}-\mathrm{N}$. There was a significant positive correlation between alkaline phosphatase and $\mathrm{NO}_{3}{ }^{-}-\mathrm{N}$. The soil saccharase was significantly positive correlated with soil phosphatase and catalase.

Table 7 shows the correlations among heavy metal concentrations, oxidative damages and enzymatic activities in plants. The $\mathrm{Pb}$ concentrations of plants were strongly positive correlated with $\mathrm{MDA}, \mathrm{H}_{2} \mathrm{O}_{2}$, and $\mathrm{O}_{2}{ }^{--}$contents in plants but were significantly negative correlated with the APX activities. The Cd concentrations of plants were significantly positive correlated with MDA contents in plants. The $\mathrm{Zn}$ concentrations of plants were significantly positive correlated with $\mathrm{H}_{2} \mathrm{O}_{2}$ contents in plants but were strongly 
TABLE 3: Concentration and total uptake of metals in ryegrass and alfalfa tissues.

\begin{tabular}{|c|c|c|c|c|c|c|}
\hline \multirow{2}{*}{ Plant } & \multirow{2}{*}{ Metal } & \multirow{2}{*}{ Treatment } & \multicolumn{2}{|c|}{ Concentration $\left(\mathrm{mg} \cdot \mathrm{kg}^{-1}\right)$} & \multicolumn{2}{|c|}{ Total uptake $\left(\mu \mathrm{g} \cdot\right.$ plant $\left.^{-1}\right)$} \\
\hline & & & Shoot & Root & Shoot & Root \\
\hline \multirow{6}{*}{ Ryegrass } & \multirow{2}{*}{$\mathrm{Pb}$} & Monoculture & $75.2 \pm 9.8^{\mathrm{a}}$ & $394 \pm 5.2^{\mathrm{a}}$ & $39.0 \pm 5.1^{\mathrm{a}}$ & $52.3 \pm 0.7^{\mathrm{a}}$ \\
\hline & & Intercropping & $30.3 \pm 0.5^{\mathrm{b}}$ & $198 \pm 7.6^{\mathrm{b}}$ & $17.2 \pm 0.3^{\mathrm{b}}$ & $35.5 \pm 1.4^{\mathrm{b}}$ \\
\hline & \multirow{2}{*}{$\mathrm{Cd}$} & Monoculture & $1.14 \pm 0.1^{\mathrm{a}}$ & $46.9 \pm 0.3^{\mathrm{a}}$ & $0.59 \pm 0.07^{\mathrm{b}}$ & $6.39 \pm 0.1^{\mathrm{a}}$ \\
\hline & & Intercropping & $1.29 \pm 0.1^{\mathrm{a}}$ & $36.5 \pm 8.9^{\mathrm{a}}$ & $0.73 \pm 0.06^{\mathrm{a}}$ & $6.57 \pm 1.6^{\mathrm{a}}$ \\
\hline & \multirow{2}{*}{$\mathrm{Zn}$} & Monoculture & $87.2 \pm 10.9^{\mathrm{a}}$ & $168 \pm 7.5^{\mathrm{a}}$ & $45.4 \pm 5.7^{\mathrm{b}}$ & $45.4 \pm 5.7^{\mathrm{b}}$ \\
\hline & & Intercropping & $94.3 \pm 4.6^{\mathrm{a}}$ & $193 \pm 24.0^{\mathrm{a}}$ & $53.6 \pm 2.6^{\mathrm{a}}$ & $53.6 \pm 2.6^{\mathrm{a}}$ \\
\hline \multirow{6}{*}{ Alfalfa } & \multirow[b]{2}{*}{$\mathrm{Pb}$} & Monoculture & $69.7 \pm 2.2^{\mathrm{a}}$ & $66.7 \pm 1.0^{\mathrm{a}}$ & $23.5 \pm 0.8^{\mathrm{a}}$ & $15.8 \pm 0.2^{\mathrm{a}}$ \\
\hline & & Intercropping & $53.8 \pm 2.4^{\mathrm{b}}$ & $26.6 \pm 6.1^{b}$ & $25.4 \pm 1.1^{\mathrm{a}}$ & $9.91 \pm 2.3^{\mathrm{a}}$ \\
\hline & \multirow{2}{*}{$\mathrm{Cd}$} & Monoculture & $2.71 \pm 0.4^{\mathrm{a}}$ & $3.84 \pm 1.3^{\mathrm{a}}$ & $0.91 \pm 0.30^{\mathrm{a}}$ & $1.16 \pm 0.01^{\mathrm{a}}$ \\
\hline & & Intercropping & $2.11 \pm 0.1^{\mathrm{b}}$ & $2.55 \pm 1.3^{\mathrm{a}}$ & $0.95 \pm 0.04^{\mathrm{a}}$ & $0.55 \pm 0.14^{\mathrm{b}}$ \\
\hline & \multirow{2}{*}{$\mathrm{Zn}$} & Monoculture & $62.3 \pm 8.9^{\mathrm{a}}$ & $33.6 \pm 5.4^{\mathrm{a}}$ & $21.0 \pm 3.0^{\mathrm{b}}$ & $7.95 \pm 1.3^{\mathrm{b}}$ \\
\hline & & Intercropping & $57.9 \pm 6.2^{\mathrm{a}}$ & $30.0 \pm 2.0^{\mathrm{a}}$ & $27.4 \pm 3.0^{\mathrm{a}}$ & $11.2 \pm 0.7^{\mathrm{a}}$ \\
\hline
\end{tabular}

Note. Values are the means \pm standard error $(n=4$. Means followed by the same letter are not significantly different at $p<0.05$.

TABLE 4: Soil enzyme activities after plant harvest under the different treatments.

\begin{tabular}{|c|c|c|c|c|c|}
\hline Treatment & $\begin{array}{c}\text { Urease } \\
\left(\mathrm{NH}_{3}{ }^{+}-\mathrm{N} \mathrm{mL} \mathrm{L}^{-1} \mathrm{~g}^{-1} 24 \mathrm{~h}^{-1}\right)\end{array}$ & $\begin{array}{c}\text { Saccharase } \\
\left(\mathrm{C}_{6} \mathrm{H}_{12} \mathrm{O}_{6} \mathrm{mg}^{-1} \mathrm{~g}^{-1} 24 \mathrm{~h}^{-1}\right)\end{array}$ & $\begin{array}{l}\text { Alkaline phosphatase } \\
\quad\left(\mu \mathrm{g} \mathrm{PNP} \mathrm{g}^{-1} \mathrm{~h}^{-1}\right)\end{array}$ & $\begin{array}{c}\text { Catalase } \\
1.1 \mathrm{~mol} \mathrm{~L}^{-1} \mathrm{KMnO}_{4} \\
\left.\mathrm{~mL}^{-1} \mathrm{~g}^{-1} 20 \mathrm{~min}^{-1}\right) \\
\end{array}$ & $\begin{array}{l}\text { Polyphenol oxidase } \\
\text { (Purpurogallin } \\
\mathrm{mg}^{-1} \mathrm{~g}^{-1} 2 \mathrm{~h}^{-1} \text { ) }\end{array}$ \\
\hline Control & $2.61 \pm 0.1^{\mathrm{ab}}$ & $7.28 \pm 1.1^{\mathrm{d}}$ & $1.45 \pm 0.06^{\mathrm{bc}}$ & $1.56 \pm 0.1^{\mathrm{b}}$ & $3.40 \pm 0.1^{\mathrm{a}}$ \\
\hline MR & $2.79 \pm 0.07^{\mathrm{a}}$ & $15.3 \pm 0.2^{\mathrm{b}}$ & $1.50 \pm 0.1^{\mathrm{b}}$ & $2.11 \pm 0.2^{\mathrm{a}}$ & $3.04 \pm 0.2^{\mathrm{b}}$ \\
\hline MA & $2.60 \pm 0.1^{\mathrm{b}}$ & $11.2 \pm 2.4^{\mathrm{c}}$ & $1.29 \pm 0.1^{\mathrm{c}}$ & $1.98 \pm 0.1^{\mathrm{a}}$ & $3.47 \pm 0.2^{\mathrm{a}}$ \\
\hline IRA & $2.70 \pm 0.01^{\mathrm{a}}$ & $20.5 \pm 0.1^{\mathrm{a}}$ & $1.70 \pm 0.09^{\mathrm{a}}$ & $2.18 \pm 0.1^{\mathrm{a}}$ & $3.37 \pm 0.3^{\mathrm{a}}$ \\
\hline
\end{tabular}

Note. Values are the means \pm standard error $(n=4)$. Means followed by the same letter in the same column are not significantly different at $p<0.05$. MR: monoculture ryegrass; MA: monoculture alfalfa; IRA: intercropping of ryegrass and alfalfa.

TABLE 5: The soil physical-chemical properties under different treatments.

\begin{tabular}{|c|c|c|c|c|c|c|c|}
\hline Treatment & $\mathrm{pH}$ & $\begin{array}{c}\text { SOM } \\
\left(\mathrm{g} \cdot \mathrm{kg}^{-1}\right)\end{array}$ & $\begin{array}{c}\mathrm{TN} \\
\left(\mathrm{g} \cdot \mathrm{kg}^{-1}\right)\end{array}$ & $\begin{array}{l}\mathrm{NO}_{3}{ }^{-}-\mathrm{N} \\
\left(\mathrm{mg} \cdot \mathrm{kg}^{-1}\right)\end{array}$ & $\begin{array}{l}\mathrm{NH}_{4}{ }^{+}-\mathrm{N} \\
\left(\mathrm{mg} \cdot \mathrm{kg}^{-1}\right)\end{array}$ & $\begin{array}{c}\text { Available P } \\
\left(\mathrm{mg} \cdot \mathrm{kg}^{-1}\right)\end{array}$ & $\begin{array}{c}\text { Available K } \\
\left(\mathrm{mg} \cdot \mathrm{kg}^{-1}\right)\end{array}$ \\
\hline Control & $8.2 \pm 0.01^{b}$ & $24.6 \pm 0.8^{\mathrm{b}}$ & $1.49 \pm 0.01^{\mathrm{a}}$ & $12.0 \pm 1.60^{\mathrm{a}}$ & $2.66 \pm 0.24^{\mathrm{b}}$ & $0.61 \pm 0.15^{\mathrm{a}}$ & $29.5 \pm 0.1^{\mathrm{a}}$ \\
\hline MR & $8.7 \pm 0.10^{a}$ & $25.8 \pm 1.8^{\mathrm{ab}}$ & $1.09 \pm 0.10^{\mathrm{b}}$ & $11.7 \pm 2.23^{\mathrm{ab}}$ & $2.65 \pm 0.16^{b c}$ & $0.58 \pm 0.05^{\mathrm{a}}$ & $22.9 \pm 0.6^{b}$ \\
\hline MA & $8.6 \pm 0.10^{\mathrm{a}}$ & $26.4 \pm 0.7^{\mathrm{a}}$ & $1.14 \pm 0.01^{\mathrm{b}}$ & $9.0 \pm 2.15^{\mathrm{b}}$ & $2.94 \pm 0.07^{\mathrm{ab}}$ & $0.36 \pm 0.10^{\mathrm{b}}$ & $22.4 \pm 0.2^{\mathrm{b}}$ \\
\hline IRA & $8.5 \pm 0.07^{\mathrm{a}}$ & $27.1 \pm 0.9^{\mathrm{a}}$ & $1.16 \pm 0.01^{\mathrm{b}}$ & $13.5 \pm 2.06^{\mathrm{a}}$ & $3.20 \pm 0.34^{\mathrm{a}}$ & $0.49 \pm 0.09^{\mathrm{ab}}$ & $23.8 \pm 0.8^{\mathrm{b}}$ \\
\hline
\end{tabular}

Note. Values are the means \pm standard error $(n=4)$. Means followed by the same letter in the same column are not significantly different at $p<0.05$. MR: monoculture ryegrass; MA: monoculture alfalfa; IRA: intercropping of ryegrass and alfalfa.

negative correlated with the POD activities. The CAT activities were significantly negative correlated with the MDA and $\mathrm{O}_{2}{ }^{-}$contents in plants. The APX activities were significantly negative correlated with the $\mathrm{MDA}, \mathrm{H}_{2} \mathrm{O}_{2}$, and $\mathrm{O}_{2}{ }^{--}$ contents in plants.

3.5. Oxidative Damage and Quantification of Enzymatic Antioxidants of Plant. To investigate the oxidative damage induced by heavy metals, lipid peroxidation was estimated by measuring MDA content (Figures 4(a) and 4(b)). Compared with the ryegrass monoculture treatment, the MDA content in the shoots was significantly decreased by $28 \%$. For alfalfa, the intercropping treatment significantly decreased the MDA content of shoots and roots by $28 \%$ and $30 \%$, respectively. The $\mathrm{O}_{2}{ }^{-}$content of ryegrass and alfalfa tissues is shown in Figures 4(c) and 4(d). The contents of $\mathrm{O}_{2}{ }^{--}$in the roots of alfalfa had no significant differences among different planning patterns. In the shoots of the alfalfa, the $\mathrm{O}_{2}{ }^{-}$contents of the intercropping treatment were significantly lower than those in the monoculture treatment by $32 \%$. For alfalfa, the intercropping treatment significantly decreased the $\mathrm{H}_{2} \mathrm{O}_{2}$ content of shoots and roots by $15 \%$ and $24 \%$, respectively (Figures $4(\mathrm{e})$ and $4(\mathrm{f})$ ).

Compared with the ryegrass monoculture treatment, the POD activity of roots was significantly increased by the intercropping treatment (Figure 5(b)). The roots POD activity of alfalfa in the monoculture and intercropping treatments showed no significant differences; however, POD activity in the shoots of alfalfa was substantially improved by the intercropping treatment (Figures 5(a) and 5(b)). Compared with the ryegrass monoculture treatment for the roots part, the CAT activity was significantly increased by the intercropping treatment (Figure $5(\mathrm{~d})$ ). For the shoots of alfalfa, the CAT activity was significantly increased by the intercropping treatment (Figure 5(c)). The APX activity in ryegrass shoots and roots in the monoculture and intercropping treatments showed no significant differences 
TABle 6: Pearson correlation matrix among soil physicochemical properties and soil enzyme activities.

\begin{tabular}{|c|c|c|c|c|c|c|c|c|c|c|c|c|}
\hline & $\mathrm{pH}$ & SOM & $\mathrm{TN}$ & $\mathrm{AP}$ & $\mathrm{AK}$ & $\mathrm{NO}_{3}{ }^{-}-\mathrm{N}$ & $\mathrm{NH}_{4}^{+}-\mathrm{N}$ & Urease & Saccharase & $\begin{array}{c}\text { Alkaline } \\
\text { phosphatase }\end{array}$ & Catalase & $\begin{array}{c}\text { Polyphenel } \\
\text { oxidase }\end{array}$ \\
\hline $\mathrm{pH}$ & 1 & & & & & & & & & & & \\
\hline SOM & 0.426 & 1 & & & & & & & & & & \\
\hline TN & $-0.957^{* *}$ & -0.481 & 1 & & & & & & & & & \\
\hline AP & -0.387 & -0.221 & 0.399 & 1 & & & & & & & & \\
\hline $\mathrm{AK}$ & $-0.745^{* *}$ & $-0.629^{* *}$ & $0.757^{* *}$ & 0.239 & 1 & & & & & & & \\
\hline $\mathrm{NO}_{3}{ }^{-}-\mathrm{N}$ & -0.231 & 0.106 & 0.160 & 0.402 & 0.105 & 1 & & & & & & \\
\hline $\mathrm{NH}_{4}{ }^{+}-\mathrm{N}$ & 0.238 & 0.425 & -0.338 & -0.485 & -0.098 & 0.161 & 1 & & & & & \\
\hline Urease & $0.580^{*}$ & 0.386 & $-0.635^{* *}$ & 0.009 & -0.370 & 0.320 & 0.020 & 1 & & & & \\
\hline Saccharase & $0.616^{*}$ & $0.505^{*}$ & $-0.662^{* *}$ & -0.209 & -0.437 & $0.525^{*}$ & $0.607^{*}$ & $0.594^{*}$ & 1 & & & \\
\hline $\begin{array}{l}\text { Alkaline } \\
\text { phosphatase }\end{array}$ & 0.021 & 0.278 & -0.057 & 0.362 & 0.001 & $0.664^{* *}$ & 0.255 & 0.293 & $0.581^{*}$ & 1 & & \\
\hline Catalase & $0.789^{* *}$ & 0.413 & $-0.787^{* *}$ & -0.162 & $-0.621^{*}$ & 0.073 & 0.401 & 0.383 & $0.719^{* *}$ & 0.229 & 1 & \\
\hline $\begin{array}{l}\text { Polyphenel } \\
\text { oxidase }\end{array}$ & -0.315 & 0.121 & 0.246 & -0.210 & 0.194 & -0.087 & 0.218 & -0.213 & -0.154 & -0.192 & -0.288 & 1 \\
\hline
\end{tabular}

Note. SOM: soil organic matter; TN: total N; AP: available P; AK: available K; ${ }^{*}$ correlation is significant at $p<0.05$ (two-tailed); ${ }^{* *}$ correlation is significant at $p<0.01$ (two-tailed).

TABle 7: Pearson correlation matrix among heavy metal concentrations, oxidative damages, and enzymatic activities in plants.

\begin{tabular}{|c|c|c|c|c|c|c|c|c|c|}
\hline & $\mathrm{Pb}$ & $\mathrm{Cd}$ & $\mathrm{Zn}$ & MDA & $\mathrm{O}_{2}^{-{ }^{-}}$ & $\mathrm{H}_{2} \mathrm{O}_{2}$ & POD & CAT & APX \\
\hline$\overline{\mathrm{Pb}}$ & 1 & & & & & & & & \\
\hline $\mathrm{Cd}$ & 0.281 & 1 & & & & & & & \\
\hline $\mathrm{Zn}$ & $0.501^{*}$ & -0.197 & 1 & & & & & & \\
\hline MDA & $0.588^{*}$ & $0.768^{* *}$ & -0.082 & 1 & & & & & \\
\hline $\mathrm{O}_{2}^{--}$ & $0.694^{* *}$ & 0.166 & 0.209 & $0.637^{* *}$ & 1 & & & & \\
\hline $\mathrm{H}_{2} \mathrm{O}_{2}$ & $0.894^{* *}$ & 0.104 & $0.520^{*}$ & 0.472 & $0.753^{* *}$ & 1 & & & \\
\hline POD & -0.271 & $0.500^{*}$ & $-0.843^{* *}$ & 0.336 & 0.183 & -0.326 & 1 & & \\
\hline CAT & -0.263 & -0.218 & -0.175 & $-0.539^{*}$ & $-0.535^{*}$ & -0.321 & 0.070 & 1 & \\
\hline APX & $-0.552^{*}$ & -0.491 & 0.042 & $-0.836^{* *}$ & $-0.775^{* *}$ & $-0.671^{*}$ & -0.136 & $0.591^{*}$ & 1 \\
\hline
\end{tabular}

Note. ${ }^{*}$ Correlation is significant at $p<0.05$ (two-tailed); ${ }^{* *}$ correlation is significant at $p<0.01$ (two-tailed).

(Figures 5(e) and 5(f)). For the shoots of alfalfa, the APX activity was significantly increased by the intercropping treatment.

\section{Discussion}

4.1. Effect of the Intercropping Treatment on Heavy Metal Uptake in Plants. It has been reported that the intercropping could enhance the availability and uptake of plant nutrients and produce substances promoting plant growth $[12,13]$. Our result indicated that the intercropping can increase the biomass of both ryegrass and alfalfa. This means that the intercropping can increase the yield of both ryegrass and alfalfa in the process of phytostabilization. Intercropping can increase the biomass of two pastures on the one hand due to the physiological characteristics of alfalfa. Alfalfa is an important leguminous forage, which can effectively fix and absorb nitrogen in the soil and air, respectively [14]. When it was intercropped with gramineous crops, the part of the fixed and absorbed nitrogen can transfer through various channels and was used by the gramineous crops, so as to improve the utilization efficiency of nitrogen $[14,15]$. On the other hand, intercropping of the leguminous and gramineous crop can separate the usage space and time from the aboveground and underground, making it efficient to use of light, heat, water, and other resources in nature, which could significantly improve the yield [6]. Chen et al. [30] reported that the intercropping of wheat and faba bean can significantly improve wheat yield, promote nutrient utilization, and effectively control disease. Furthermore, the $\mathrm{N}$ and chlorophyll concentration of plant was significantly increased under the intercropping treatment compared with the monoculture treatments. The results also verify the above two hypotheses. This means that intercropping could promote the growth of two pastures by increasing levels of plant nitrogen and chlorophyll.

Intercropping of different plants can regulate the accumulation of heavy metals in plants $[31,32]$. In the present study, our result showed that intercropping can significantly decrease $\mathrm{Pb}$ concentration in ryegrass and alfalfa tissues (Table 3). It means that the intercropping patterns of ryegrass and alfalfa can significantly reduce the $\mathrm{Pb}$ uptake from soil to achieve the purpose of phytostabilization. It can provide us with a strategy that intercropping of ryegrass and alfalfa can be used on the $\mathrm{Pb}$-contaminated soil. It has been reported that ryegrass has a strong ability to absorb cadmium; thus, intercropping could not reduce the accumulation of cadmium in plants [33]. Similar studies showed that the $\mathrm{Pb}$ concentrations in maize grain and cabbage were significantly lower when they were intercropped with 


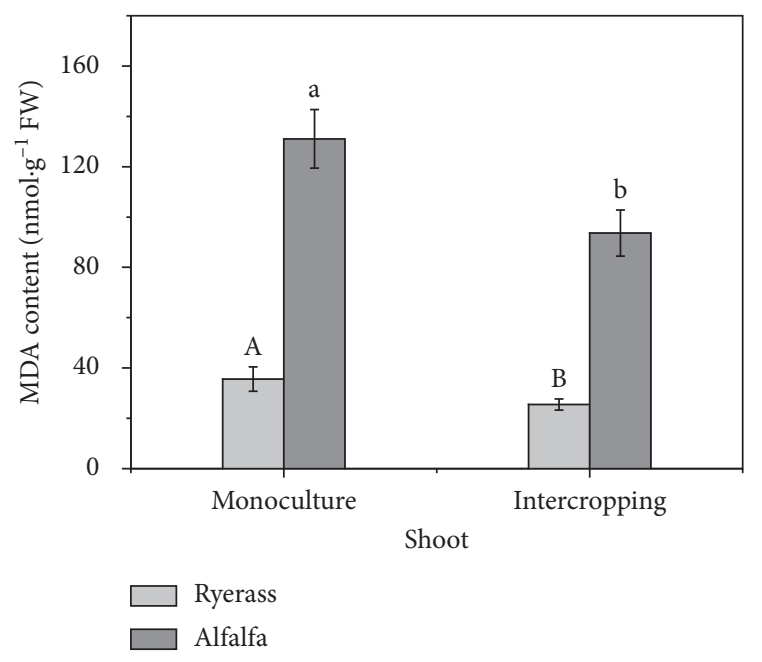

(a)
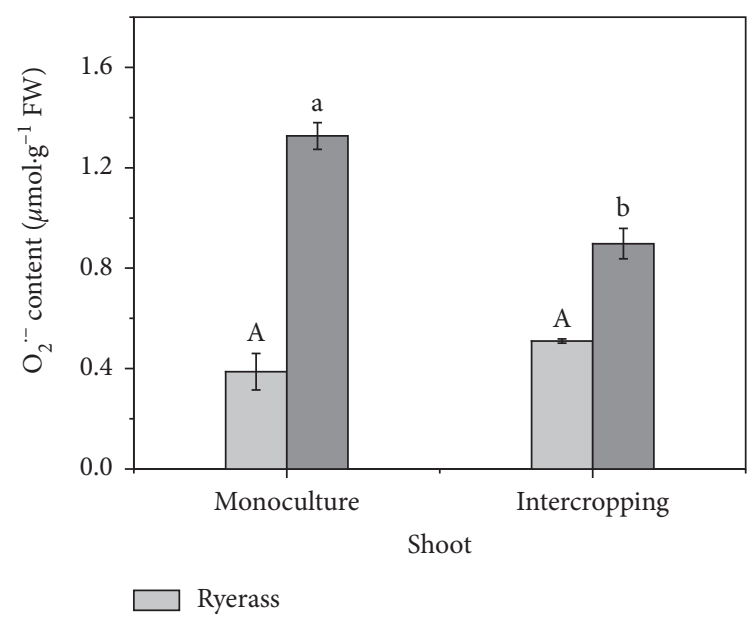

Alfalfa

(c)

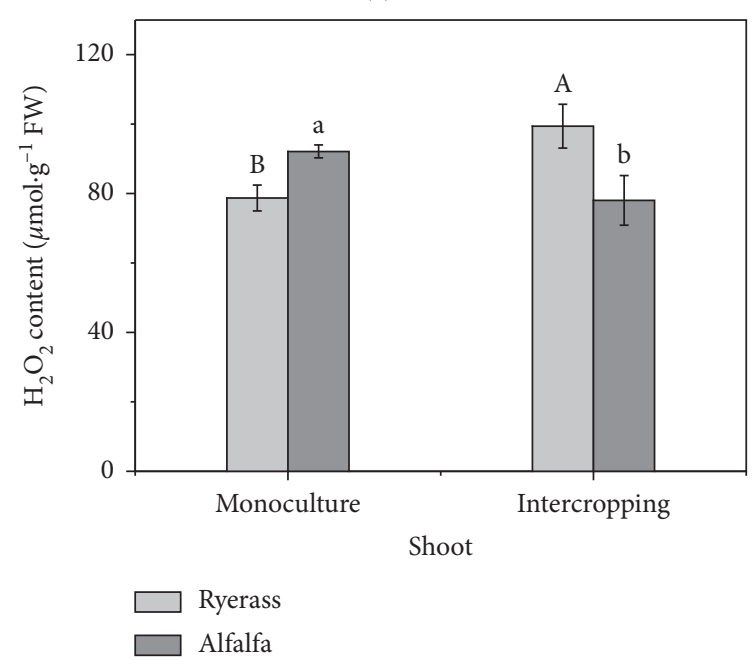

(e)

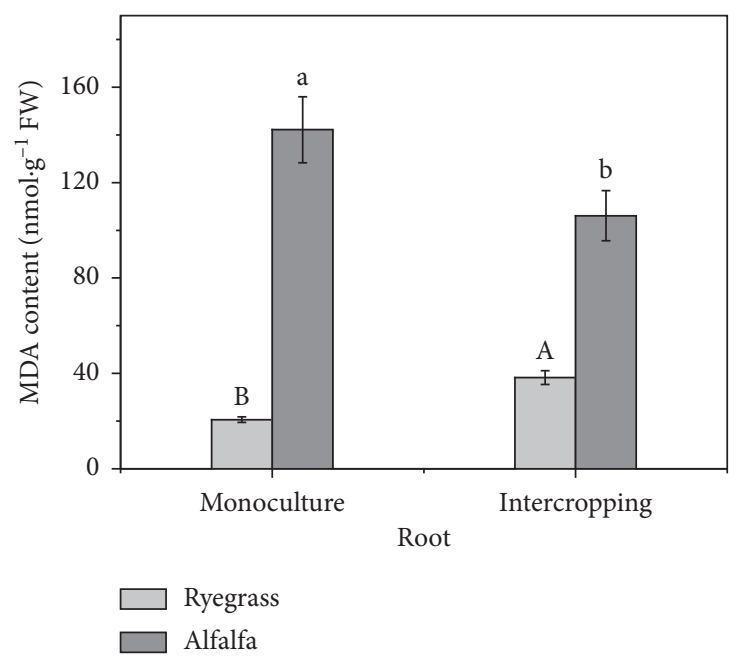

(b)

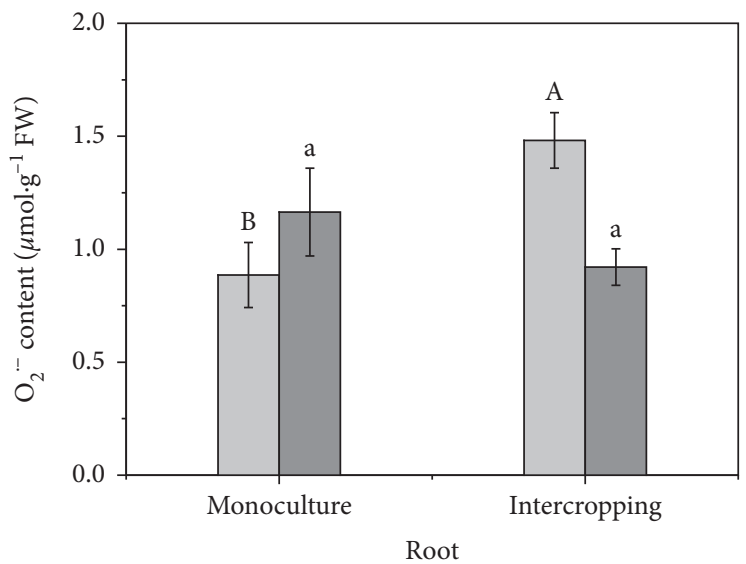

Ryegrass

Alfalfa

(d)

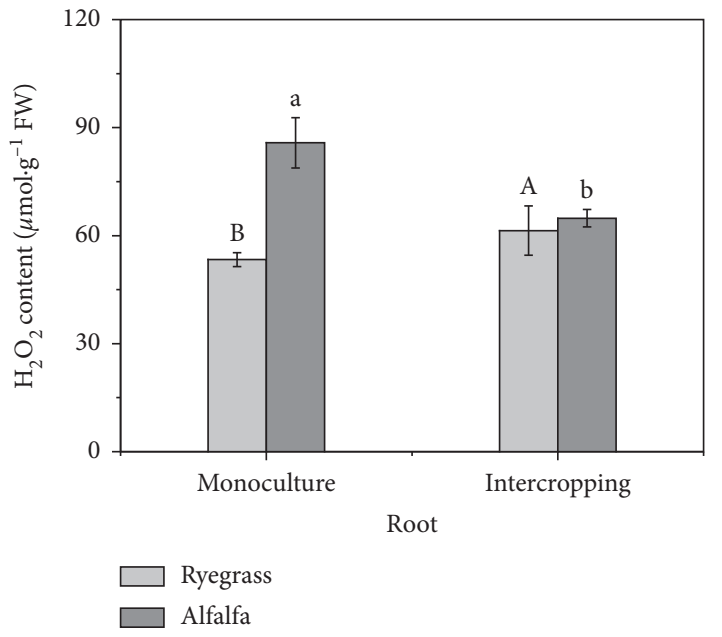

(f)

Figure 4: The MDA, $\mathrm{O}_{2}^{--}$and $\mathrm{H}_{2} \mathrm{O}_{2}$ content in shoots and roots of ryegrass and alfalfa under the monoculture and intercropping treatments. MDA content in shoots (a), MDA content in roots (b), $\mathrm{O}_{2}^{--}$content in shoots (c), $\mathrm{O}_{2}^{--}$content in roots $(\mathrm{d}), \mathrm{H}_{2} \mathrm{O}_{2}$ content in shoots (e), and $\mathrm{H}_{2} \mathrm{O}_{2}$ content in roots (f). Bars are the standard error $(n=3)$. Means followed by the same letter are not significantly different at $p<0.05$ of ryegrass and alfalfa with different treatments. 


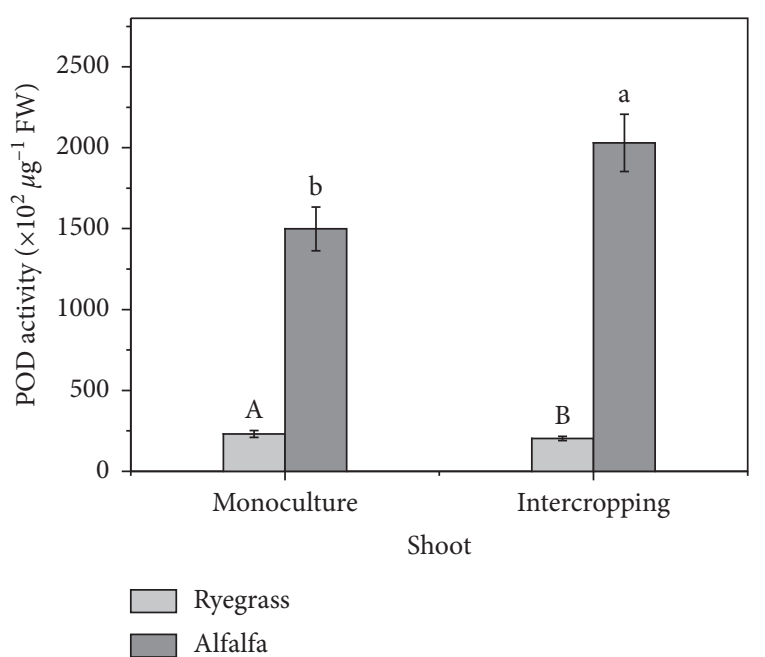

(a)

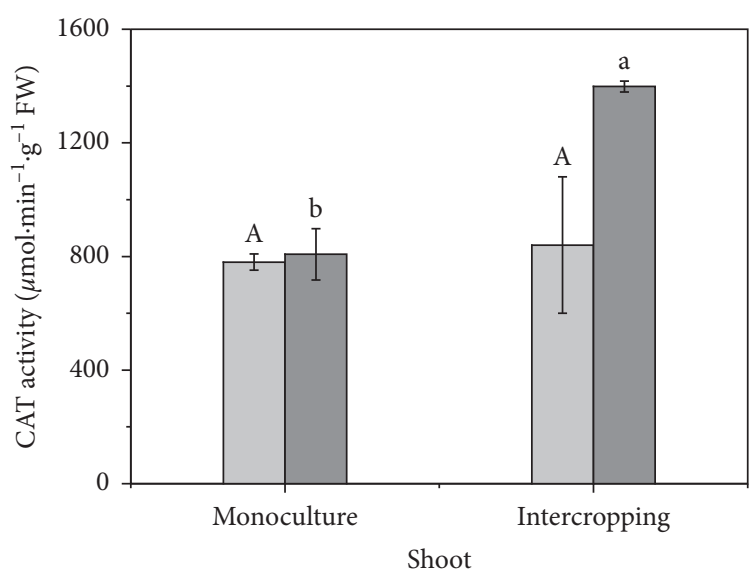

$\square$ Ryegrass

$\square$ Alfalfa

(c)

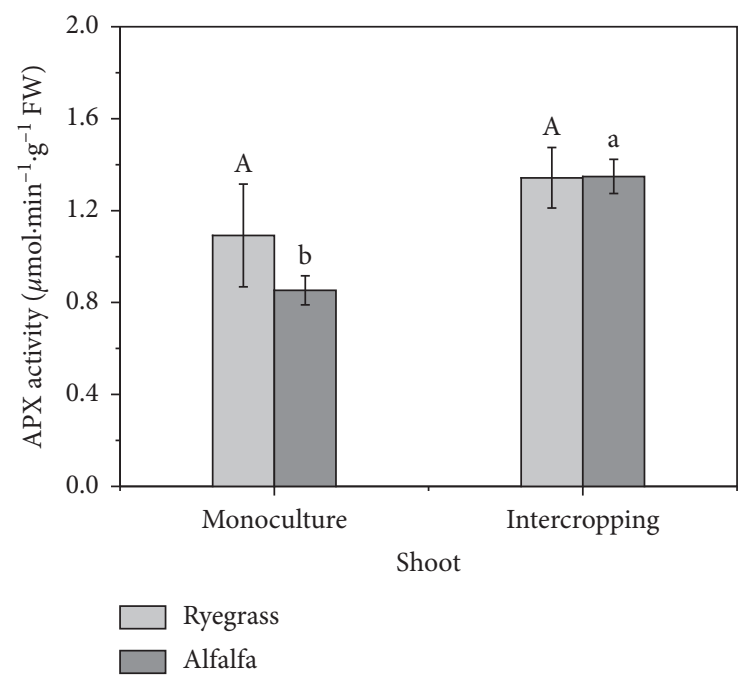

(e)

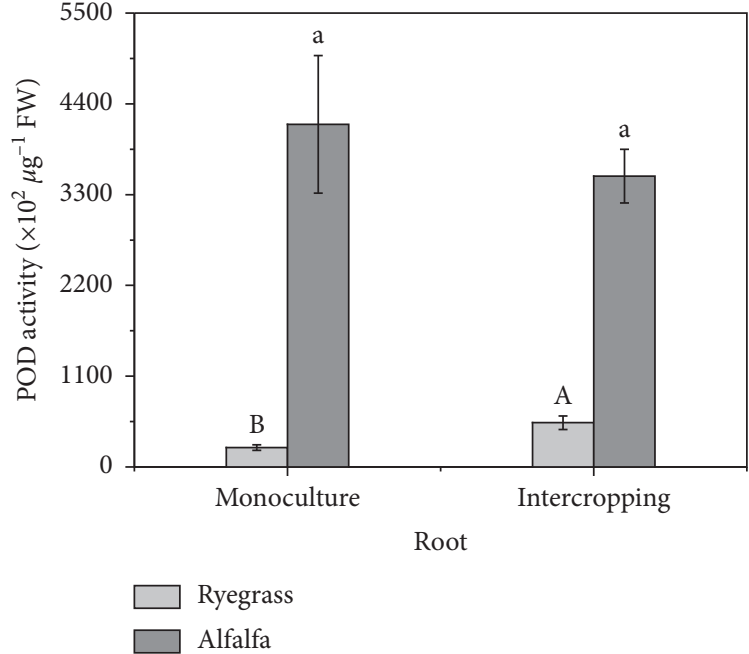

(b)

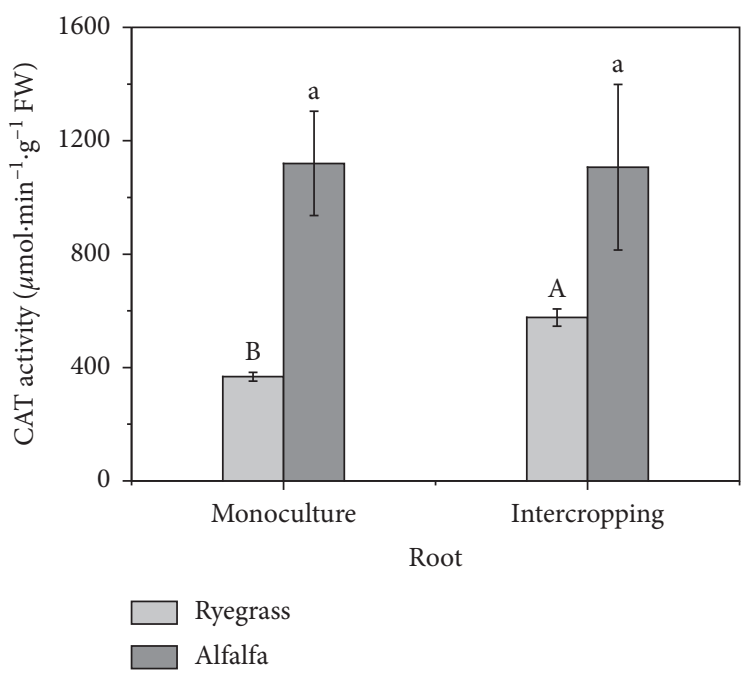

(d)

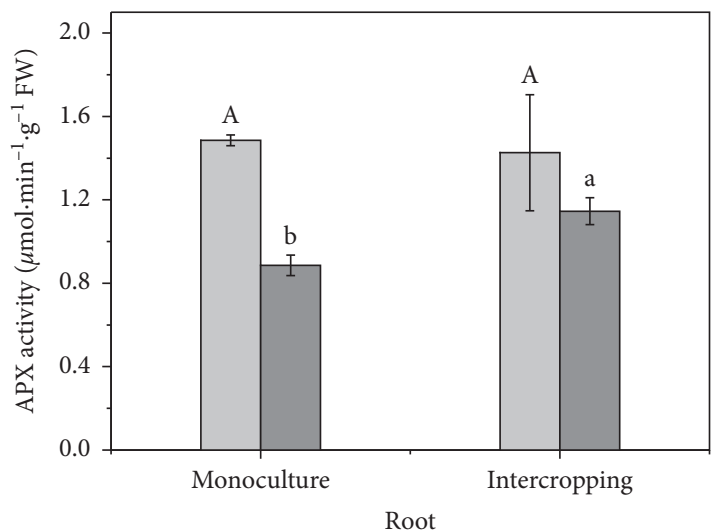

Ryegrass

Alfalfa

FIGURE 5: The antioxidant enzyme system contents in shoots and roots of ryegrass and alfalfa under the monoculture and intercropping treatments. POD activity in shoots (a), POD activity in roots (b), CAT activity in shoots (c), CAT activity in roots (d), APX activity in shoots (e), and APX activity in roots (f). Bars are standard error $(n=3)$. Means followed by the same letter are not significantly different at $p<0.05$ of ryegrass and alfalfa with different treatments. 
Japanese clover than when the respective crops were grown in monoculture $[9,34]$. In this study, the ability of heavy metal uptake of ryegrass roots was much higher than that of alfalfa. Ryegrass can absorb heavy metals around the roots so as to provide a relatively safe environment for roots. Ryegrass and alfalfa intercropping may form roots interlaced each other to provide a safe living environment for alfalfa to reduce the concentrations of heavy metals in alfalfa. Wang et al. [9] found that the intercropping of Pteris vittata L. and faba bean can not only reduce the As content in the soil around the roots of Pteris vittata. L but also reduce the As content in the soil around the roots of faba bean. The intercropping could reduce the heavy metals in the bean. Correspondingly, the nitrogen fixation at the root of alfalfa can provide nutrients to ryegrass to enhance the resistance of ryegrass to heavy metals. It has been reported that nitrogen was an important detoxification factor for cadmium stress in plants [35]. Phytostabilization could eliminate the availability of toxic metals in soil through complexing with metals by certain plants root exudates [4]. Intercropping may increase the amount of root secretions by promoting the growth and development of plant roots. Zhan et al. [7] found that the intercropping of Sonchus asper L. and Vicia faba L. could decrease the effectiveness of heavy metals in soil by changing the low molecular weight organic acids secreted by the root system. Intercropping may increase the amount of root secretions by promoting the growth and development of plant roots. Previous studies working on intercropping treatment reported that it could reduce heavy metals contents in the plants [8]. The effects of the planting pattern on metal accumulation in plants may also depend on types of the metal and interactions between two coexisting plant species. In this study, intercropping not only reduced the $\mathrm{Pb}$ accumulation in plants but also increased plants biomass.

\subsection{Effect of the Intercropping Treatment on the Resistance of} Plants to Heavy Metals. Although the physical and chemical properties of the soil has no significant changes under different treatments, the intercropping treatment has the highest values of soil SOM, TN, $\mathrm{NH}_{4}{ }^{+}-\mathrm{N}, \mathrm{NO}_{3}{ }^{-} \mathrm{N}$, and $\mathrm{AP}$. This means that intercropping may promote the growth and development of plant roots by improving the physical and chemical properties of soil. Moreover, soil enzyme activity plays an important role and is usually recommended as standard biological indicators of soil health [36, 37]. Soil enzyme activity is critically important for soil quality and can provide indications of changes in metabolic capacity and nutrient cycling due to management practices [38, 39]. In turn, soil mineral nutritional factors may support the growth and metabolic activity of plants. In this study, soil saccharase and alkaline phosphatase enzyme activities were affected by the intercropping treatment. Urease, catalase, and polyphenol oxidase had no significant change among different planted patterns. This means that intercropping can improve soil nutrient metabolism by improving soil saccharase and alkaline phosphatase enzyme activities. The increase in alkaline phosphatase may be due to intercropping which increases the P cycle in the soil [40]. Li et al. [41] founded that chickpea can improve the alkaline phosphatase in both hydroponic and soil cultures, leading to an interspecific facilitation in utilization of organic $P$ in maize/chickpea intercropping.

In this study, Pearson correlation clarified that the dominant urease, saccharase, and catalase were significantly positive correlated with soil $\mathrm{pH}$ but were significantly negative correlated with soil TN (Table 6). Saccharase was significantly positive correlated with soil $\mathrm{NH}_{4}^{+}-\mathrm{N}$ and $\mathrm{NO}^{-}{ }_{3}-\mathrm{N}$. It means that $\mathrm{pH}$ and $\mathrm{TN}$ were the main factors affecting the activity of soil enzyme. Alkaline phosphatase was significantly positive correlated with soil $\mathrm{NO}_{3}{ }^{-}$-N. It has been reported that the content of phosphatase and soil $\mathrm{P}$ in intercropping treatment is positively correlated [41]. Our result showed that soil urease was significantly negative correlated with soil TN.

The superfluous accumulation of ROS (reactive oxygen species) caused oxidative stress in plants, especially for sensitive cellular membranes. MDA is the ultimate decomposition product of membrane lipid peroxidation, which is the expression of the degree of peroxidation of plant cell membrane, and its content can reflect the degree of damage of the plant [42]. The higher the content of MDA indicated that the higher the degree of peroxidation of the plant cell membrane, the more serious damage to the cell membrane. MDA can be typically used as the indicator of lipid peroxidation in plants, which has been certified by previous studies [43]. $\mathrm{O}_{2}{ }^{-2}$ is the free radical which is first formed in the oxygen metabolism of the organism, and it is the precursor of all the oxygen radicals. $\mathrm{H}_{2} \mathrm{O}_{2}$ is an important component of ROS. Excessive heavy metals can cause oxidative stress in the plant body and increase the $\mathrm{H}_{2} \mathrm{O}_{2}$ level and lipid peroxidation in plants [43, 44]. Similarly in Arabidopsis, oxidative stress after exposure to $\mathrm{Cd}$ is due to $\mathrm{H}_{2} \mathrm{O}_{2}$ accumulation [45]. A decrease of MDA content indicates that the oxidation degree of plant cell membrane is decreased, and the destruction of cell membrane is decreased. A decrease of $\mathrm{O}_{2}{ }^{-}$content can reduce cell structure damage and prevent plant physiological disorders. The decreased $\mathrm{H}_{2} \mathrm{O}_{2}$ of ROS content can alleviate oxidative damage. In present study, compared with the alfalfa monoculture treatment, intercropping significantly decreased MDA, $\mathrm{H}_{2} \mathrm{O}_{2}$, and $\mathrm{O}_{2}{ }^{--}$contents in plant shoots and roots, except for the $\mathrm{O}_{2}{ }^{--}$content of alfalfa roots (Figure 4). The $\mathrm{Pb}$ concentrations of plants were significantly correlated with MDA, $\mathrm{H}_{2} \mathrm{O}_{2}$, and $\mathrm{O}_{2}{ }^{--}$contents in plants (Table 7), which indicated that intercropping treatment can decrease the harmful substance and alleviate oxidative damage under heavy metal stress. The results indicated that intercropping treatment can mitigate the toxic effects of heavy metals by decreasing the harmful substance and alleviating oxidative damage. At the cellular level, excessive heavy metals can cause the physiological imbalance between oxygen-free radicals and plant antioxidant enzymes in plants [43, 44]. The enzymatic antioxidant system, including CAT, APX, and POD, is capable of scavenging excess ROS and prevent plants from lipid peroxidation. For instance, plants can protect cells from the damage of excessive ROS caused by 
environmental stress through a strong antioxidant enzyme activity $[46,47]$.

In plant cells, the POD, CAT, and APX play vital roles in regulating the $\mathrm{H}_{2} \mathrm{O}_{2}$ level for signaling during metabolic changes, but the POD and APX are proposed to be predominantly responsible for modulating the $\mathrm{H}_{2} \mathrm{O}_{2}$ level, especially under the heavy metals stress environments [45]. In present study, compared with the monoculture treatment, intercropping significantly increased POD and CAT activities in the shoots of alfalfa (Figure 5). The APX activity in alfalfa shoots and roots was significantly increased by the intercropping treatment. And the CAT and APX activities were significantly negative correlated with the MDA and $\mathrm{O}_{2}{ }^{-}$ contents in plants; this means the intercropping treatment can decrease the harmful substance and alleviate oxidative damage under heavy metal stress by increasing the antioxidant enzyme system. Under the heavy metals stress, plants usually clear reactive oxygen radicals by strengthening protection on enzyme activity to maintain stability and integrity of cell membrane. Many results indicated that the increase of enzymatic antioxidant enzymes in plants would lead to decrease in the concentration of $\mathrm{Pb}$ in plants [48]. Overall, the response of alfalfa to heavy metals with decreasing the oxidative damage and increasing the antioxidant enzyme system could alleviate heavy metals toxicity in plants.

\section{Conclusions}

The present study demonstrated that intercropping of ryegrass and alfalfa treatment can promote plant growth and increase plant biomass in the heavy metal-contaminated soil. The plants grown in the intercropping treatment had a significantly low $\mathrm{Pb}$ concentration in plant shoots and roots than those in the monoculture treatments, which could be contributed to the reduction of oxidative damage and increase of enzymatic antioxidant activities in plants under intercropping. Hence, the intercropping of these two forage species could be a potentially safe phytoremediation pattern to reduce heavy-metal risks and increase yield in a large scale under heavy metal-contaminated soils. Further research is required to completely understand the mechanism of the interaction between the roots of two plants in intercropping conditions.

\section{Data Availability}

The data used to support the findings of this study are available from the corresponding author upon request.

\section{Conflicts of Interest}

The authors declare that there are no conflicts of interest regarding the publication of this paper.

\section{Acknowledgments}

This work was financially supported by the National Natural Science Foundation of China (41571314 and 41201226) and CAS "Light of West China" Program (XAB2016A03).

\section{References}

[1] L. Chen, S. Luo, X. J. Li, Y. Wan, J. B. Chen, and C. B Liu, "Interaction of Cd-hyperaccumulator Solanum nigrum, L. and functional endophyte Pseudomonas, sp. Lk9 on soil heavy metals uptake," Soil Biology and Biochemistry, vol. 68, no. 1, pp. 300-308, 2014.

[2] X. S. Luo, Y. Xue, Y. L. Wang, L. Cang, B. Xu, and J. Ding, "Source identification and apportionment of heavy metals in urban soil profiles," Chemosphere, vol. 127, pp. 152-157, 2015.

[3] H. Ali, E. Khan, and M. A. Sajad, "Phytoremediation of heavy metals-concepts and applications," Chemosphere, vol. 91, no. 7, pp. 869-881, 2013.

[4] E. A. Gwozdz and M. Kopyra, "Plant cell responses to heavy metals-biotechnological aspects," Biotechnologia, vol. 3, pp. 107-123, 2003.

[5] A. A. Erakhrumen, "Phytoremediation: an environmentally sound technology for pollution prevention, control and remediation in developing countries," Educational Research Review, vol. 2, no. 7, pp. 151-156, 2007.

[6] F. S. Zhan and L. Li, "Using competitive and facilitative interactions in intercropping systems enhances crop productivity and nutrient-use efficiency," Plant and Soil, vol. 248, no. 1-2, pp. 305-312, 2003.

[7] F. D. Zhan, L. Qin, X. H. Guo et al., "Cadmium and lead accumulation and low-molecular-weight organic acids secreted by roots in an intercropping of a cadmium accumulator Sonchus asper L. with Vicia faba L," RSC Advances, vol. 6, no. 40, pp. 33240-33248, 2016.

[8] L. Y. Lin, X. L. Yan, X. Y. Liao, Y. X. Zhang, and X. Ma, "Arsenic accumulation in Panax notoginseng monoculture and intercropping with Pteris vittata," Water, Air, and Soil Pollution, vol. 226, no. 4, p. 113, 2015.

[9] S. Q. Wang, S. H. Wei, D. D. Ji, and J. Y. Bai, "Co-planting Cdcontaminated field using hyperaccumulator Solanum nigrum L. through interplant with low accumulation welsh onion," International Journal of Phytoremediation, vol. 17, no. 9, pp. 879-884, 2015.

[10] X. M. Wan, M. Lei, T. B. Chen, and J. X. Yang, "Intercropped Pteris vittata L. and Morus alba L. presents a safe utilization mode for arsenic-contaminated soil," Science of the Total Environment, vol. 579, pp. 1467-1475, 2016.

[11] C. Li, Y. Dong, H. Li, J. Shen, and F. Zhang, "The dynamic process of interspecific interactions of competitive nitrogen capture between intercropped wheat (Triticum aestivum L) and faba bean (Vicia faba L.)," PLoS One, vol. 9, no. 12, Article ID e115804, 2014.

[12] Y. M. Zuo, X. L. Li, Y. P. Cao, and F. S. Zhang, "Effect of maize/peanut intercropping on iron nutrition of peanut," Plant Nutrition and Fertilizer Science, vol. 3, no. 2, pp. 153159, 1997.

[13] H. E. Dessougi, A. Z. Dreele, and N. Claassen, "Growth and phosphorus uptake of maize cultivated alone in mixed culture with other crops or after incorporation of their residues," Journal of Plant Nutrition and Soil Science, vol. 166, no. 2, pp. 254-261, 2003.

[14] H. Hauggaard-Nielsen, M. Gooding, P. Ambus et al., "Pea-barley intercropping for efficient symbiotic $\mathrm{N}_{2}$-fixation, soil $\mathrm{N}$ acquisition and use of other nutrients in European organic cropping systems," Field Crops Research, vol. 113, no. 1, pp. 64-71, 2009.

[15] C. J. Li, Y. Y. Li, C. B. Yu et al., "Crop nitrogen use and soil mineral nitrogen accumulation under different crop combination and patterns of strip intercropping in northwest China," Plant and Soil, vol. 342, no. 1-2, pp. 221-231, 2011. 
[16] T. Gunther, U. Dornberger, and W. Fritsche, "Effects of ryegrass on biodegradation of hydrocarbons in soil," Chemosphere, vol. 33, no. 2, pp. 203-215, 1996.

[17] S. A. Cheema, M. I. Khan, C. F. Shen et al., "Degradation of phenanthrene and pyrene in spiked soils by single and combined plants cultivation," Journal of Hazardous Materials, vol. 177, no. 1-3, pp. 384-389, 2010.

[18] L. Meng, M. Qiao, and H. P. H. Arp, "Phytoremediation efficiency of a $\mathrm{PAH}$-contaminated industrial soil using ryegrass, white clover, and celery as mono- and mixed cultures," Journal of Soils and Sediments, vol. 11, no. 3, pp. 482-490, 2011.

[19] K. Wang, H. G. Huang, Z. Q. Zhu et al., "Phytoextraction of metals and rhizoremediation of PAHs in co-contaminated soil by co-planting of Sedum alfredii with ryegrass (Lolium perenne) or castor (Ricinus communis)," International Journal of Phytoremediation, vol. 15, no. 3, pp. 283-298, 2012.

[20] M. Arienzo, P. Adamo, and V. Cozzolino, "The potential of Lolium perenne for revegetation of contaminated soil from a metallurgical site," Science of the Total Environment, vol. 319, no. 1-3, pp. 13-25, 2004.

[21] J. T. Si, B. G. Tian, H. T. Wang, B. Nicholas, S. Jackie, and C. Mark, "Assessing availability, phytotoxicity and bioaccumulation of lead to ryegrass and millet based on $0.1 \mathrm{~mol} / \mathrm{L}$ $\mathrm{Ca}\left(\mathrm{NO}_{3}\right)_{2}$ extraction," Journal of Environmental Sciences, vol. 18, pp. 958-963, 2006.

[22] H. Dai and G. Jia, "Effects of Se on the growth, tolerance, and antioxidative systems of three alfalfa cultivars," Environmental Science and Pollution Research, vol. 24, no. 6, pp. 1-6, 2017.

[23] T. Thayalkumaran, B. H. Robinson, I. Vogeler, D. R. Scotter, B. E. Clothier, and H. J. Percival, "Plant uptake and leaching of copper during EDTA-enhanced phytoremadiation of repacked and undisturbed soil," Plant and Soil, vol. 254, no. 2, pp. 415-423, 2003.

[24] S. K. Dong, M. Y. Kang, and X. J. Yun, "Economic comparison of forage production from annual crops, perennial pasture and native grassland in the alpine region of the QinghaiTibetan Plateau, China," Grass and Forage Science, vol. 62, no. 4, pp. 405-415, 2007.

[25] S. Buckingham, E. Tipping, and J. Hamilton-Taylor, "Dissolved organic carbon in soil solutions: a comparison of collection methods," Soil Use and Management, vol. 24, no. 1, pp. 29-36, 2008.

[26] K. Yan, W. Chen, G. Y. Zhang et al., "Elevated $\mathrm{CO}_{2}$ ameliorated oxidative stress induced by elevated $\mathrm{O}_{3}$ in Quercus mongolica," Acta Physiologiae Plantarum, vol. 32, no. 2, pp. 375-385, 2010.

[27] S. Y. Guan, Soil Enzyme and its Research Approaches, China Agriculture Press, Beijing, China, 1986, in Chinese.

[28] F. Eivazi and M. A. Tabatabai, "Phosphatases in soils," Soil Biology and Biochemistry, vol. 9, no. 3, pp. 167-172, 1977.

[29] F. Eivazi and M. A. Tabatabai, "Glucosidases and galactosidases in soils," Soil Biology and Biochemistry, vol. 20, no. 5, pp. 601-606, 1988.

[30] Y. X. Chen, F. S. Zhang, and L. Tang, "Wheat powdery mildew and foliar $\mathrm{N}$ concentration as influenced by $\mathrm{N}$ fertilization and belowground interactions with intercropped with faba bean," Plant and Soil, vol. 291, no. 1-2, pp. 1-13, 2007.

[31] J. W. Huang, J. J. Chen, W. R. Berti, and S. D. Cunningham, "Phytoremediation of lead-contaminated soils: role of synthetic chelates in lead phytoextraction," Environmental Science and Technology, vol. 31, no. 3, pp. 800-805, 1997.

[32] Y. H. Chen, Z. G. Shen, and X. D. Li, "The use of vetiver grass (Vetiveria zizanioides) in the phytoremediation of soils contaminated with heavy metals," Applied Geochemistry, vol. 19, no. 10, pp. 1553-1565, 2004.
[33] T. Li, W. H. Xu, Y. R. Chai, Z. Y. Wang, and D. T. Xie, "Differences of Cd uptake and expression of Cd-tolerance related genes in two varieties of ryegrasses," Bulgarian Chemical Communications, vol. 49, no. 9, pp. 697-705, 2017.

[34] L. Liu, L. L. Hu, J. J. Tang, Y. F. Li, Q. Zhang, and X. Chen, "Food safety assessment of planting patterns of four vegetable-type crops grown in soil contaminated by electronic waste activities," Journal of Environmental Management, vol. 93, no. 1, pp. 22-30, 2012.

[35] F. Zhang, X. Wan, and Y/ Zhong, "Nitrogen as an important detoxification factor to cadmium stress in poplar plants," Journal of Plant Interactions, vol. 9, no. 1, pp. 249-258, 2013.

[36] J. H. Xue and Y. X. Fei, "Effects of intercropping Cunninghamia lanceolata in tea garden on contents and distribution of heavy metals in soil and tea leaves," Journal of Ecology and Rural Environment, vol. 22, no. 4, pp. 71-74, 2006.

[37] M. B. Hinojosa, J. A. Carreira, J. M. Rodríguez-Maroto, and R. García-Ruíz, "Effects of pyrite sludge pollution on soil enzyme activities: ecological dose-response model," Science of the Total Environment, vol. 369, no. 2-3, pp. 89-99, 2008.

[38] Y. Gao, P. Zhou, L. Mao, Y. E. Zhi, C. H. Zhang, and W. J. Shi, "Effects of plant species coexistence on soil enzyme activities and soil microbial community structure under $\mathrm{Cd}$ and $\mathrm{Pb}$ combined pollution," Journal of Environmental Sciences, vol. 22, no. 7, pp. 1040-1048, 2010.

[39] L. C. Fang, Y. Q. Liu, H. X. Tian, H. S. Chen, and Y. Q. Wang, "Proper land use for heavy metal-polluted soil based on enzyme activity analysis around a $\mathrm{Pb}-\mathrm{Zn}$ mine in Feng County, China," Environmental Science and Pollution Research, vol. 24, no. 36, pp. 28152-28164, 2017.

[40] S. Saha, V. Prakash, S. Kundu, N. Kumar, and B. L. Mina, "Soil enzymatic activity as affected by long term application of farm yard manure and mineral fertilizer under a rainfed soybean wheat system in N-W Himalaya," European Journal of Soil Biology, vol. 44, no. 3, pp. 309-315, 2008.

[41] S. M. Li, L. Li, F. S. Zhang, and C. Tang, "Acid phosphatase role in chickpea/maize intercropping," Annals of Botany, vol. 94, no. 2, pp. 297-303, 2004.

[42] C. J. Duan, L. C. Fang, C. L. Yang, W. B. Chen, Y. X. Cui, and S. Q. Li, "Reveal the response of enzyme activities to heavy metals through in situ zymography," Ecotoxicology and Environmental Safety, vol. 156, pp. 106-115, 2018.

[43] J. Chen, W. H. Wang, T. W. Liu, F. H. Wu, and H. L. Zheng, "Photosynthetic and antioxidant responses of Liquidambar formosana and Schima superba seedlings to sulfuric-rich and nitric-rich simulated acid rain," Plant Physiology and Biochemistry, vol. 64, no. 5, pp. 41-51, 2013.

[44] R. Mittler, "Oxidative stress, antioxidants and stress tolerance," Trends in Plant Science, vol. 7, no. 9, pp. 405-410, 2002.

[45] U. H. Cho and N. H. Seo, "Oxidative stress in Arabidopsis thaliana exposed to cadmium is due to hydrogen peroxide accumulation," Plant Science, vol. 168, no. 1, pp. 113-120, 2005.

[46] M. Hojati, S. A. Modarressanavy, S. T. Enferadi et al., "Cadmium and copper induced changes in growth, oxidative metabolism and terpenoids of Tanacetum parthenium," Environmental Science and Pollution Research, vol. 24, no. 13, pp. 1-12, 2017.

[47] F. Morina, L. Jovanović, L. Prokić, and S. Veljovićjovanović, "Physiological basis of differential zinc and copper tolerance of Verbascum populations from metal-contaminated and uncontaminated areas," Environmental Science and Pollution Research, vol. 23, no. 10, pp. 10005-10020, 2016.

[48] S. Verma and R. S. Dubey, "Lead toxicity induces lipid peroxidation and alters the activities of antioxidant enzymes in growing rice plants," Plant Science, vol. 164, no. 4, pp. 645-655, 2003. 

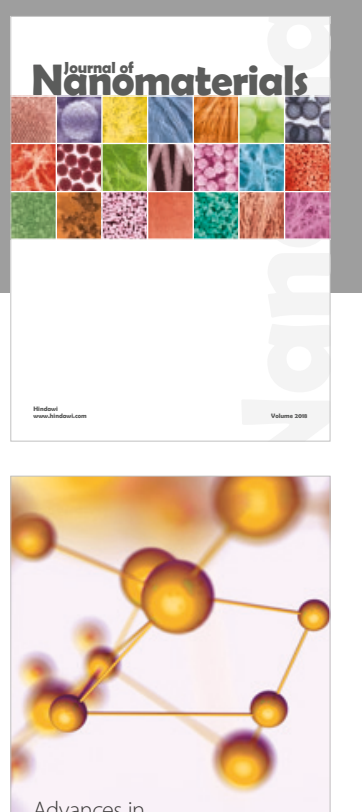

Physical Chemistry
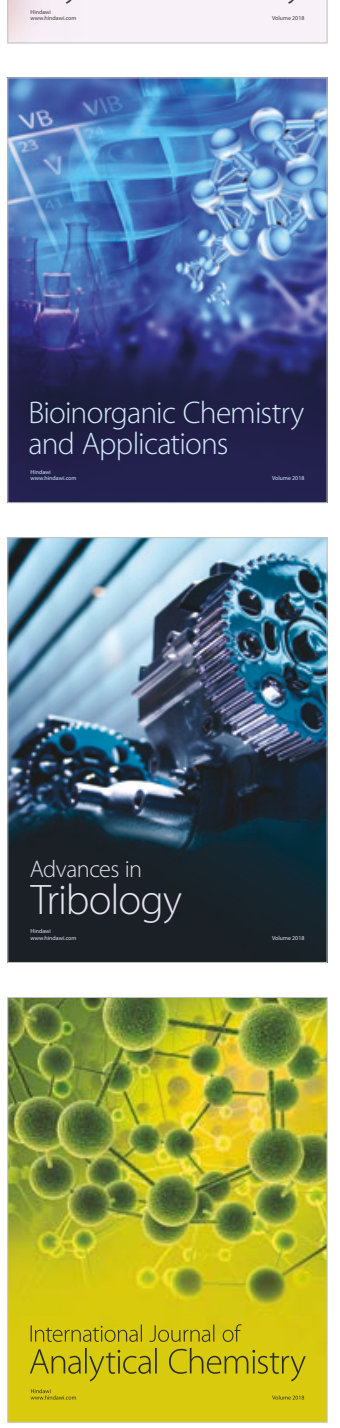

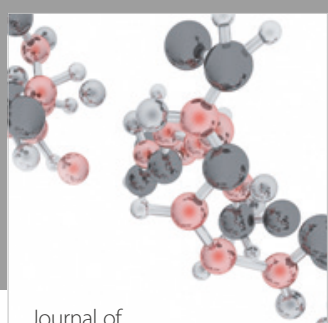

Analytical Methods

in Chemistry

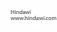

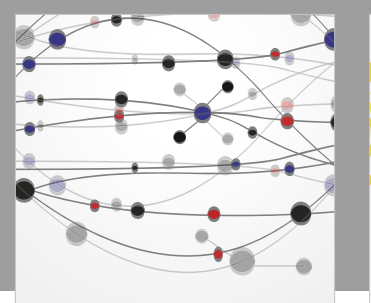

The Scientific World Journal

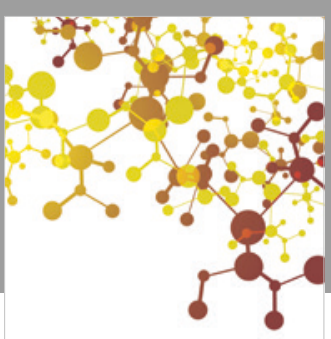

Journal of

Applied Chemistry
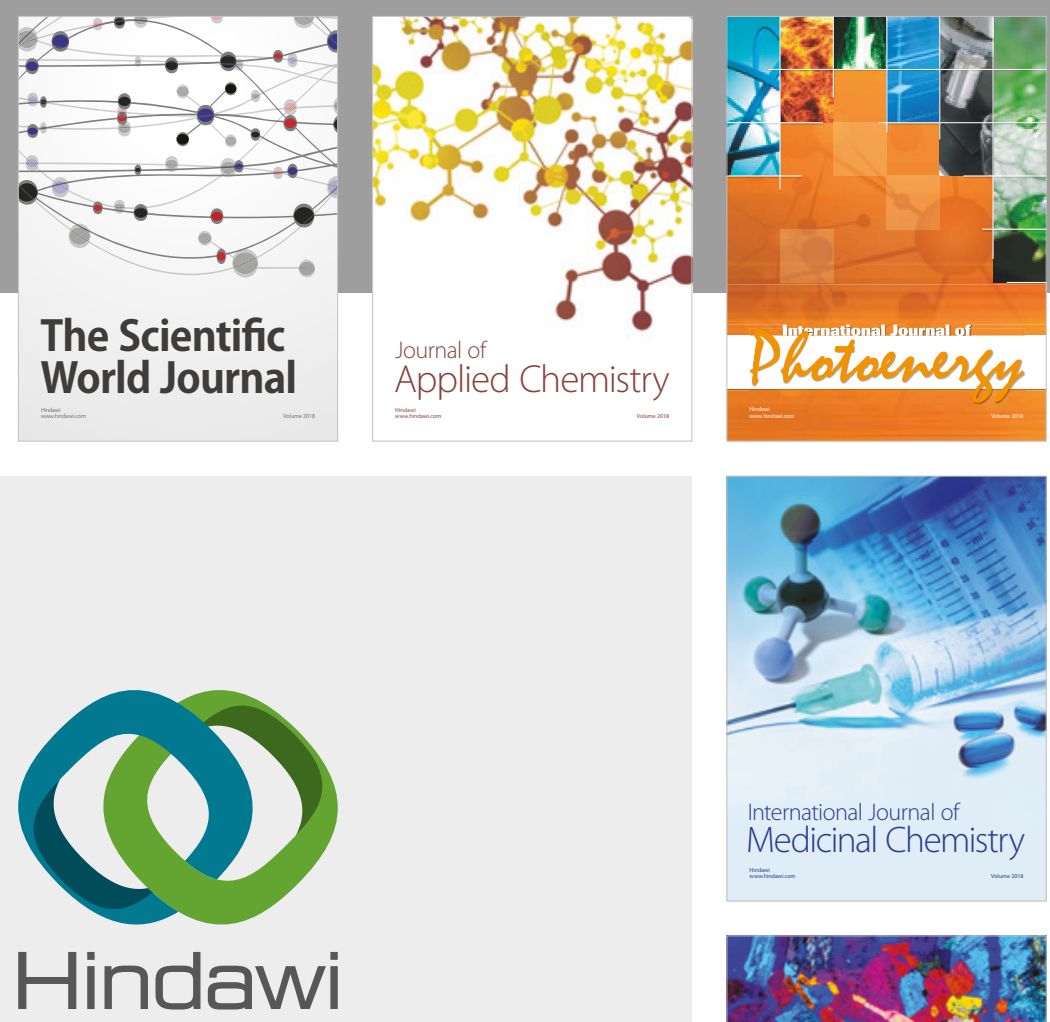

Submit your manuscripts at

www.hindawi.com
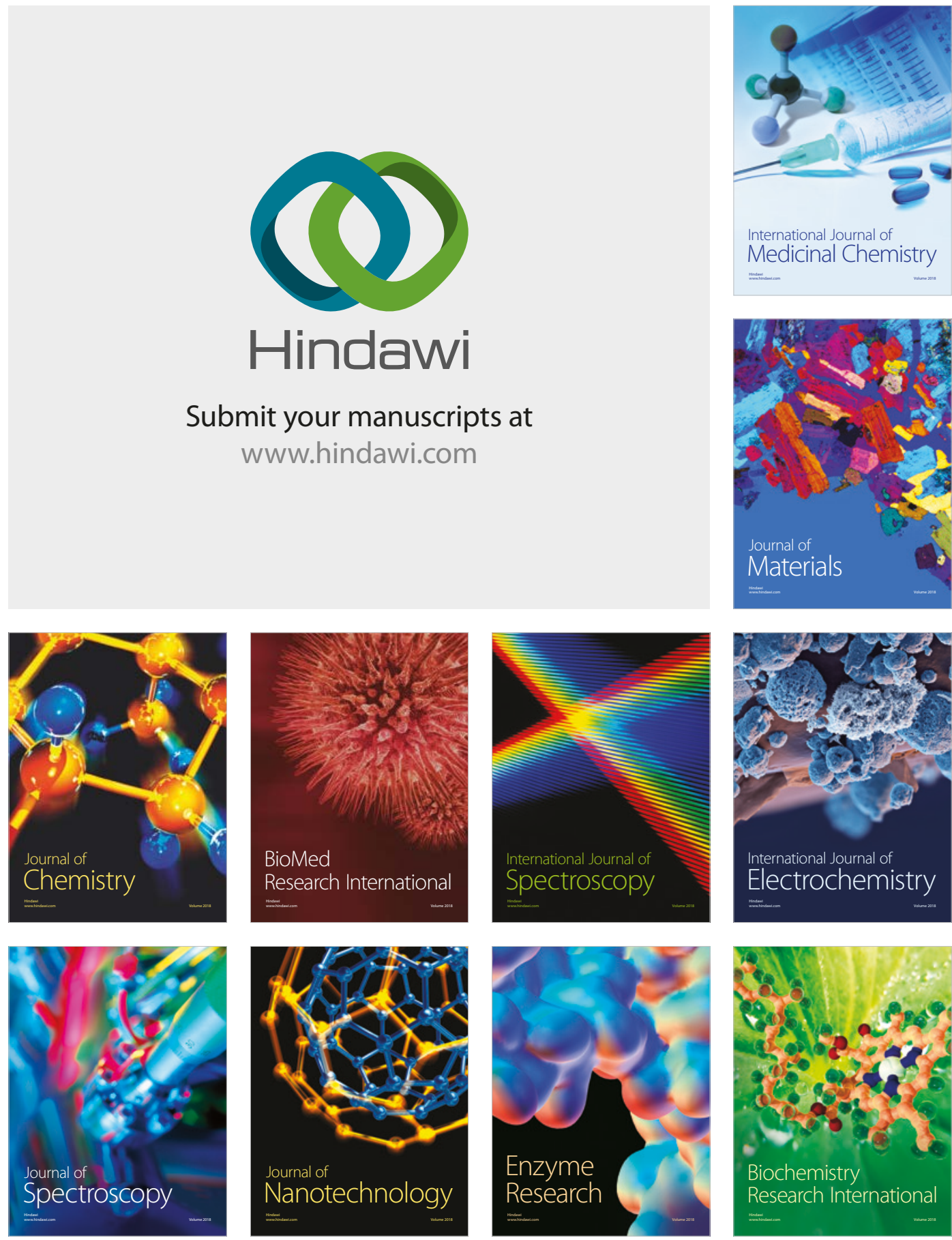
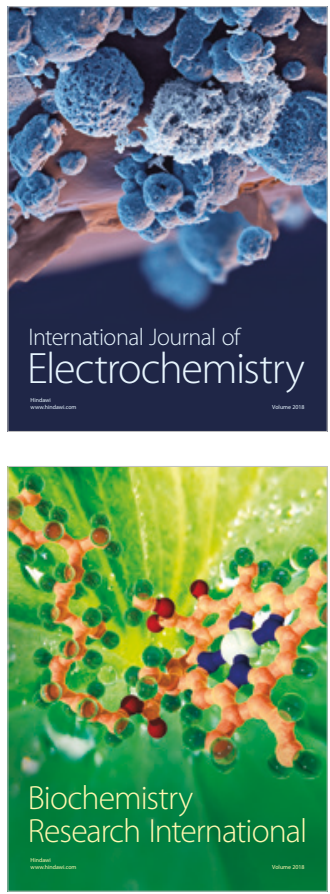